\title{
Policy Evaluation Of Restructuring Street Vendors in Surakarta City (Study of Street Vendors in Monument Park Banjarsari and Street Vendors in Manahan Stadium)
}

\author{
Frahlevi Prajasari ${ }^{1 *}$, Andy Fefta Wijaya ${ }^{2}$, Choirul Saleh $^{3}$ \\ ${ }^{1}$ Fastrack Master Program, Faculty of Administrative Sciences, University of Brawijaya, Malang \\ ${ }^{2}$ Faculty of Administrative Sciences, University of Brawijaya, Malang \\ ${ }^{3}$ Faculty of Administrative Sciences, University of Brawijaya, Malang
}

\begin{abstract}
This study examined the policy evaluation of restructuring street vendors in Surakarta city. Street vendors represent the economic actors in the informal sector of urban economic activity. The government of City/District usually removes these street vendors by disguising this activity behind the reason of structuring, . The study used descriptive research with a qualitative approach. The relocation of street vendors in Surakarta City is orderly and smooth without violence which may impact badly on physic and material because the government of Surakarta City, especially Surakarta Mayor, uses persuasive approach. Notoharjo Market is a relocation place for street vendors at Banjarsari Monument Park. In the beginning, Notoharjo Market is crowded with buyers but current days, street vendors who occupy Notoharjo Market complain about lack of buyers. The lack of buyers at Notoharjo Market is because the facilities previously provided by the government of Surakarta City are not well maintained. The government of Surakarta City must listening all complains of street vendors for the smoothness and orderliness of trading activity of street vendors. Not only listening, but the government of Surakarta City also gives appropriate and best solution to street vendors such that street vendors feel comfort in selling and their income is better than before.
\end{abstract}

Keywords: Evaluation of Public Policy, Street Vendors, Sustainable Development, Street Vendors in Monument Park Banjarsari and Manahan Stadium.

\section{INTRODUCTION}

Street vendors represent the economic actors in the informal sector of urban economic activity. The dramatic urban growth has triggered the urbanization from the rural. However, it only increases the population of the city, although the economical or socio-cultural growth in the urban is becoming well developed. According Manning and Effendi [1] One form of the informal sector that will further the street, as Street Vendors categorized as type of work important and relatively distinctive in the informal sector .

In several cases at big cities, the presence of street vendors is considered disturbing the traffic and obscuring the beauty of the city. The government of City/District usually removes these street vendors by disguising this activity

\footnotetext{
* Correspondence Address:

Frahlevi Prajasari

Email : frachlevhy@yahoo.com

Address : Jl. Bawonomanis III/1 RT.31/RW.08, Desa

Manisrejo, Kecamatan Taman, Kota Madiun, 63138
}

behind the reason of structuring. However, street vendors quickly emerge again after removal. The conflict of interest between the beauty and structuring over the city in one hand, and the demand of survival among traders in other hand, seems endless.

Rural employment is evident due to the shrinkage of farming lands (either due to land conversion or the inheritance toward many beneficiaries, such that it produces land narrowing per farmer family). Rural job opportunity out of agricultural sector is not widely opened, and therefore, it only increases urbanization rate. These urban migrants do not have special skill beyond agriculture. The limited employment at formal sector forces them into informal sector, and one job in this informal sector is street vendors.

Every citizen of Indonesia has a right to work and to get paid for their survival. It is stated in National Constitution, Article 28 D Verse (2), which mentions that "Every citizen has a right to 
work and to get paid in fair and reliable fashions in the work relationship". Therefore, it is the duty of the government, including the government of district/city, to help their citizens in their authorized region to obtain employment in favor of reliable life.

Street vendors refer to one job of the trade field but it is a real manifestation of informal sector. Indeed, street vendors are businesspeople with quite low capital who work in the production and selling of goods (services) to meet the demand of certain group in the community. This business is positioned at strategic places in the informal environment.

The structuring over street vendors in big cities is once accompanied with dead victim. In September 2007, two singing-beggar kids and one newspaper delivery kid are subjected to hitting of three Regional Guardian Polices of the Government of Probolinggo City during the raid. This case is submitted to the court by the parent of the victim. In May 2009, two children are becoming the dead victim during the raid by the regional guardian polices. First occurrence is on May 11th, when a kid named Siti Khoiriyah (4 years old) must suffer from burn injury at almost all her body parts because of accidentally showered by hot broth during the raid operation against street vendors around Boulevard, Pemuda Street, Surabaya. Khoiriyah has been treated more or less a week at Public Hospital (RSUD) of Dr. Soetomo Surabaya. But on May 18th, around $15.15 \mathrm{pm}$, Khoiriyah passes away (Okezone news, 2009).

Some street vendors attempt to accept the removal with sincere heart but with the compatible indemnification. They perceive that their building is built on the legal land, and it is not surprising if they show aggressive behavior against removal. Such aggressive behavior is demonstrated by giving abusive words, pushing and hitting the officer during the removal, although not all removal processes are needed with clash and violence act by street vendors.

Sasono who says that there are two views to understand informal sector, which are [2]:

1. Informal sector has a right to live and develop because it helps the development to supply the employment for the people with less education, knowledge and skill.

2. Informal sector does not have a right to live because it only disturbs the efficiency of economic development, intrudes the order and cleanliness of the city, and stands for the strict competitive against formal sector.

One factor behind the increased number of street vendors in Surakarta City is the imbalance between the number of workforce and the job opportunity that shall be given based on education background. In addition to the limited job opportunity, employment at formal sector requires classification that is hardly attended by the workforce with minimum education. Many workforces shift into informal sector by being street vendors because it is a quite potential job.

The presence of street vendors cannot be separated from the growth of certain region. It also prevails in Surakarta with the spread of traders who use the bank of the street, which is truly representing the development of the city itself. It is reasonable then if the government does the structuring sometimes, but it only causes misunderstanding. The structuring of street vendors faces two contradictive sides. Like two sides of coin, the structuring involves contradictive goals. It may trigger a dispute between trader and government.

Surakarta is a quite successful region in managing the orderliness of the city. The government of this city has been recognized for the successful structuring of street vendors in various points. However, some problems related to the structuring of street vendors are still shadowing the governmental action, mainly in the markets where street vendors are relocated from several regions. Although it is not $100 \%$ successful, but the structuring of street vendors at Surakarta can be modeled at national level.

The successful of restructuring street vendors in Surakarta it caused the mayor policy about restructuring street vendors. It proved with "zero growth population of Street Vendors in Surakarta", it means that after relocation there was no increasing amount of street vendors, and the income of street vendors was better (data of market dept.of Surakarta 2010) According Thomas R. Dye formulate public policy as all the choices or actions taken by the government, public policy regarding any choices made by the government, either to do something or not to do something [3]. It proved that the mayor do something with persuasive approach torestructuring Street vendors. Meanwhile, according to Islamy public policy generally interpreted as, "A series of actions are defined and implemented or not implemented by the government which has the purpose or goal- 
oriented particular interest for the entire community [4].

Surakarta City has developed into a big city and therefore, it cannot escape from street vendors. Based on the field data collected by heads of village and heads of subdistrict per September 2009 in Surakarta City, there are 5,847 street vendors at 51 villages and 5 subdistricts who sell food/beverage, fruit, cloth, cigarette, mobile phone voucher, spare part, staple, kid toy, ornament plant, electronic device, furniture, and animal. The location of street vendors is categorized into five. First category is street vendors who occupy Slamet Riyadi Street and General Sudirman Street. Second category is those who sell along the main highway of the city. Third category is around Banjarsari Monument. Meanwhile, fourth is around Manahan Stadium. Finally, fifth is at the road between environments and the settlement road throughout subdistrict. Keeping street vendors in the order is realized in favorable fashion, with almost without riot, by using persuasive approach. The policy of street vendors is arranged within Local Regulation No. 3 of 2008 about the Management of Street Vendors at Surakarta City.

The research attempts to evaluate whether the policy of structuring vendors in this city is well managed similar to that during the leadership of Jokowi or even worse. It is important matter because Surakarta City has been the model city for the structuring of street vendors. Further, Jones explained that the evaluation was an effort to compare between what was planned and the results achieved [5].

The purposes of this research was examined and analyzed : (1) the process of Policy Evaluation of Restructuring Street Vendors In Surakarta City (2) the supporting and inhibiting factors of Evaluation of Restructuring Street Vendors In Surakarta City (3) the evaluation of Policy Evaluation Of Restructuring Street Vendors In Surakarta City (Banjarsari and Manahan stadium street vendors).

\section{RESEARCH METHOD}

In the study, the author used descriptive research with a qualitative approach. Research sites in the central park Banjarsari and Manahan Stadium at Jl. Adi Sucipto in Solo Central Java.

\section{Data Collection Techniques}

The process of data collection in qualitative research to move from area to construct empirical theories based on the information obtained in the field. Lofland and Lofland (1984,p.45) asserts that in the context of data collection, there are three activities, namely: the process of entering the study site (entrance), whereas in the study area (hang), and the phase of data collection (logging data). The process of data collection in this study, as described in the following stages:

1. The process of entering the area (Getting)

This process is also an attempt to create conditions such that the ability of community researchers received research subject, and then gain the trust of the study subjects. To obtain valid data, the researchers also conducted an informal approach to the process of learning and adaptation to the environment and the process of learning from data sources in a relationship with a polite and sympathetic to reduce the social distance between researcher and informant, and thus the process of getting in can run smoothly without barriers.

2. When Being in Area Studies (Associate)

When the research sites (associate), researchers have tried to build trust by making an effort to close a close personal relationship with an informant who became the object of study. In this process, researchers have been able to get more information, and captures the essence of the meaning of the information obtained. In this case, the researchers hope to be allowed to use secondary data in the form of copies of documents, files, and images of the target institutions, can be achieved and has conducted research and analysis papers in place.

3. Logging the data

a. Indepth Interviews

With in-depth interviews, researchers have obtained the information in the form of empirical data related to the research focus. In the interview, there was a question and answer directly to the key informants as a resource so that the researchers ended up getting the required data related to the research focus. In addition, researchers also conducted interviews with other information related to the research problem.

The interview process is conducted independently or in which the researchers did not use a structured interview guide that has been specified or arranged in systematic data collection and complete, but it will be the only form of interview guide explains the problems that encourage informants. In interviews, the researchers noted in the interview outline. The results of the interview are not registered or 
recorded structures generally still rough notes or conversations that must be mixed with the main focus the conversation than an interview, the researchers made a more systematic picture of the interview. Summary results are then separated by whether or not the data is important, then do the grouping. Relationships with each other and then built the data, generate pattern and certain meaning. Some data is still in doubt-and that is still biased, asked the old data source or a new order to gain certainty and clarity.

\section{b. Documents}

Documents and records used to obtain the data through written material in the form of relocation problems of street vendors and street vendors evaluations of relocation policy. In addition to the documents and or alternative sources of information, the researchers used data documentation from various credible sources, such as journals or scientific publications. Similarly, the study of literature, became one part of the documentation.

\section{Data Analysis Techniques}

The main principle in the analysis of the data is how to make the data or information that has been collected is presented in the form and provide a description of the meaning or interpretation of that information has a significant scientific or theoretical.

Data analysis is a very important step, because by doing data analysis can then be used to solve problems and achieve the ultimate goal of the research by making conclusions that can be told to others. Miles and Huberman stated that data analysis in qualitative research carried out at the time of data collection in progress and after completion of the data collection period [6]. , Miles and Huberman argued that qualitative data analysis has steps, as follows:

\section{Data collection}

Activities undertaken by a researcher to obtain valid data, either a primary data and secondary data.

\section{Data reduction}

Activities undertaken by a researcher to choose the subject matters in a way disaggregated, simplified, aggregated, searchable themes and patterns, and summarized to focus on the important things that give direction to the research focus. These results obtained data more clearly in line with the focus of research in order to draw conclusions.

3. Data display
Researchers compiled information obtained by the systematic and descriptive.

4. Conclision : Drawing / verifying

Once the information has been able at Narrate, researchers then perform data verification research. Verification is done by drawing conclusions according data obtained from various sources, then the researchers to conclude that the data temporarily while looking for support or reject the conclusions. At this stage also, researchers conducted a study about the conclusions that have been drawn with comparable data based on a particular theory. This test is intended to see the truth of the analysis that gave birth to a credible conclusion.

\section{RESULT}

1. Street Vendors Restructuring Policy and Street Vendors Relocation Process in Surakarta City

Surakarta City gives serious attention to the presence of street vendors. Although some constraints impede, the restructuring and fostering of street vendors are continued. The attention given by the government of Surakarta City toward street vendors is increasing during the administration of Jokowi (Joko Widodo, Surakarta Mayor). The socialization has begun in 2005 and it is followed by the realization of street vendors restructuring in 2006. It proves that all parties have work hard for solution. The relocation of Klithikan street vendors from the open field of Banjarsari Monument Park to the glorious permanent building in Notoharjo Market is celebrated by "Boyongan" ritual, reflecting the humane approach for street vendors restructuring. The construction of shelters is started at Manahan Stadium complex.

This hard work deserves the recognition of Surakarta City as the learning site (a comparison study) for the government of District and the government of City throughout regions of Indonesia to learn about the restructuring of street vendors. Social Friendship Day on December 20 of 2006 is celebrated at Manahan Stadium, and the President of Indonesia Republic gives an appreciation to the government of Surakarta City for the restructuring of street vendors.

Street vendors in Surakarta City are increasing in number and occupying inappropriate site in highway and public space. The background of someone to become street vendors, according to Alisjahbana [7], includes: 
(1)They are forced to be street vendors because they do not have job at formal sector but they must feed the demand of subsistence and family, because they cannot find reliable place for opening the business, and because they do not have quite reliable education and capital to open formal business.

(2)They still insist on making good money than being beggar, robber, or other criminal job.

(3)They want to be independent of other, including their parent.

(4)They work to feed the family, to improve their wellbeing, and to make it as main job rather than side job because it is harder to make income in their rural area.

Street vendors restructuring policy at Surakarta City has been implemented by relocating street vendors from Banjarsari Monument Park to Notoharjo Market. The relocation of street vendors to Notoharjo Market is followed by the provision of supporting facilities including the construction of new route for public transport to pass by Notoharjo Market because Notoharjo Market is far away from the center of Surakarta City. Second facility is the publication of new location through banner, local newspaper, and local television in Surakarta City. Third facility is live music event at Notoharjo Market organized by the government of Surakarta City. Fourth facility is that street vendors can occupy cleaner Notoharjo Market by free of charge.

\section{Factors Supporting and Constraining The Restructuring of Street Vendors \\ a. Supporting Factors}

The implementation of the policy is not separated from supporting factors from the inside or outside of organization. Supporting factors are indeed behind the success of the implementation of street vendors restructuring policy. Internal and external supporting factors are found. These factors are the source of motivation and strength for the government of Surakarta City to make progressive step toward the cleaner and beautiful Surakarta City.

Successful restructuring of street vendors through relocation cannot escape from the action by the government of Surakarta City to treat street vendors in humane way, and therefore, the restructuring of street vendors is smooth and orderly. The concrete solutions include free of charge shelter, new building of Notoharjo Market, easy permit conferral, managerial training, and financial grant from Ministry of Cooperative for 5 billions 90 millions. The objectives of street vendors restructuring are to produce harmonic urban space order with general and social facilities, to provide the business certainty for street vendors, and to empower community economic.

These supporting factors are aligned with Soenarko [8] who say that: successful implementation of a policy is influenced by agreement, support and trust from community; the content and goal of policy must be understood; the implementation must have adequate information about the condition and the awareness of the target; the division of job must be effective; the division of authority and discretion must be rational for the implementation; the division of task and duty must be reliable for the implementation.

\section{b. Constraining Factors}

The implementation of a policy represents an essence of a policy with the option of to implement or not to implement (Thomas R. Dye, 1978, p.75) but with final impact on public. Implementation stage is the heaviest and the most serious stumble stone against the effectiveness of policy at education, social and economical fields in the developing countries due to the scarcity of resource, the careless formulation and the resistance of target group.

Less favorable or even disappointing impact of social policies indicate that main problem is within implementation. According Berman [9] that the failure of social policy at education, health, welfare, house and settlement fields is caused by less effective implementation of policy. Not all programs can be implemented directly in effective manner. This indication is called by Dunshire as "Implementation Gap" which is a condition where a policy is subjected to the difference between the expectation (planning) by the policy maker and the actual result (the achievement by implementer). Implementation gap not only impedes the achievement of policy but also brings negative impact on the sustainability of a program/policy.

Constraining factors for street vendors may involve among other the hesitance of street vendors to the restructuring by the government of Surakarta City. They hesitate because they fear of losing buyers after restructuring. Some street vendors are relocated, but other still remain in the old location because they lack of buyers. The supporting facilities are not effectively implemented. Other constraint is the presence of street vendor adventurer, who has received new spot for selling but it is given to the family or sold 
to the seller, and asks for new spot again from the government of Surakarta City.

These constraining factors are the source of motivation for the government of Surakarta City to implement street vendors restructuring policy in better way. Many steps are taken by the government of Surakarta City to deal with the constraints, by increasing the effectiveness of supporting facilities such as adding public transport to pass by Notoharjo Market, empowering the promotion through local newspaper and local television, and increasing other supporting facilities to support trading activity of street vendors.

\section{Evaluation Over Street Vendors}

Restructuring Policy

Evaluation over a policy is very important and even necessary. It is not only reviewing the result of policy to ensure whether it meets the demand and interest of community, but also understanding whether the activity is already efficient and effective with real benefit. Further, Jones[10] explains that evaluation is to compare between the condition before and after the implementation of policy. It is described in Patton and Sawicki [11] with their "before and after comparison" method to review the object of research by comparing the condition before and after a policy or a program implemented. The implementation of restructuring policy for street vendors at Banjarsari Monument Park is by moving them to Notoharjo Market. Notoharjo Market is a market built and specialized for street vendors from Banjarsari Monument Park and the spot is given free of charge.

The restructuring policy of Banjarsari Monument Park street vendors is by relocating them to more strategic place for trading. When street vendors make their trading at Banjarsari Monument Park, the traffic around Banjarsari Monument Park becomes disordered and it produces congestion. Banjarsari Monument Park is a public area for recreation or tourism. Street vendors at Manahan Stadium are quite crowded before they are restructured and given shelter facility. Manahan Stadium is a place for national football matches. If the match begins, the congestion is so prominent around Manahan Stadium, and the image of Surakarta City is deteriorated.

In addition to their negative impression, street vendors have also positive side as mentioned by Alisjahbana [12], who states that "economic activities by street vendor informal sector in the developing countries are progressing. Some environmental problems due to street vendors include problems of cleanliness, beauty, orderliness, pollution and traffic congestion. All of these are disturbing, in one side, and but in other side, it gives big contribution to the economic activities and the welfare of weak economic group. Informal activities are the distinctive marker of people economic which is self-dependent and for the welfare of many people".

Based on the data and the result of interview with street vendors, the author attempts to analyze the evaluation over street vendors restructuring policy based on the opinion of Prof. Otto Soemarwoto in Sutisna [13] who proposes yard points for sustainable development. These yard points are useful for the central or local governments to assess the success of a head of government in implementing sustainable development. Three yard points are considered. Pro-welfare economic. It means that economic growth is aimed for the welfare of whole members of community and it is made to realize through innovative technology with minimum impact on environment.

Pro-sustainable environment. It means that nonanthropocentric environment ethic is the manual of life of the community because the community always keeps the preservation and the balance of environment and the conservation of vital natural resource, and prioritizes toward the improvement of life quality.

Pro-social justice. It means that just and equal access to natural resource and public service is respecting the diversity of culture and the equality of gender.

First yard point is Pro-Welfare Economic. Based on the author's evaluation over street vendors restructuring policy from Banjarsari Monument Park to Notoharjo Market, it seems that the policy is well implemented in early to middle part of the year. Almost all street vendors report that their income increases and they have many buyers. However, in the observation in 2013, many street vendors complain. There are 96 street vendors or $15 \%$ who trade at Notoharjo Market who experience loss due to lack of buyers. The relocation of street vendors to Notoharjo Market is making them far away from the center of Surakarta City. It is not big problem if the government of Surakarta City improves the effectiveness of previous facilities. Public transport which passes by Notoharjo Market is reactivated. Notoharjo Market is broadcasted and promoted through local newspaper and local 
television. People entertainment through live music event can attract the interest of community to come to Notoharjo Market and to buy the items sold by street vendors at Notoharjo Market. Considering this result, from the interview or the obtained data, it is said that the evaluation over street vendors restructuring policy at Notoharjo Market is not yet meeting Pro-Welfare Economic yard point because not all street vendors relocated to Notoharjo Market are satisfied and happy. It is because there are $15 \%$ street vendors at Notoharjo Market who feel lacked of buyers such that the relocation of street vendors to Notoharjo Market cannot meet Pro-Welfare Economic yard point.

Second yard point is Pro-Sustainable Environment. As evaluated and analyzed by the author, street vendors are relocated from Banjarsari Monument Park which is the public space, to Notoharjo Market which is far from the center of Surakarta City. It signifies that the government of Surakarta City has met ProSustainable Environment yard point. The relocation of street vendors from Banjarsari Monument Park means that the government of Surakarta City cares about the environment of Banjarsari Monument Park. Before relocation, Banjarsari Monument Park is filled with dirt, congestion and less comfort for hanging around. The worse is that Banjarsari Monument Park is located at the center of Surakarta City.

Third yard point is Pro-Social Justice. Street vendors restructuring policy has met the criteria of Pro-Social Justice. Street vendors are relocated to more reliable and cleaner place with free of charge supporting facilities. Shelter is given for street vendors at Manahan Stadium and this reflects the attention of the government of Surakarta City to the small people, especially street vendors.

Based on data obtained by the author and from the interview, the restructuring of street vendors at Manahan Stadium is almost without complaint about buyers. The shelter helps street vendors to trade in orderly and tidy ways. If analyzed from first yard point, Pro-Welfare Economic, street vendors at Manahan Stadium have met Pro-Welfare Economic yard point. Although they have met Pro-Welfare Economic yard point, their trading is as usual. Some street vendors admit that they have greater income.

Second yard point is Pro-Sustainable Environment. The restructuring of street vendors has met Pro-Sustainable Environment yard point because the shelter around Manahan Stadium is constructed without cutting the tress around Manahan Stadium. Some big shading trees remain intact around Manahan Stadium.

Third yard point is Pro-Social Justice. Measured from Pro-Social Justice yard point, street vendors restructuring policy has met ProSocial Justice. It is shown by the relocation of street vendors to the cleaner and more reliable place and the provision of free supporting facilities including shelter. The construction of shelter for street vendors at Manahan Stadium is reflecting the care of the government of Surakarta City to small people, including street vendors.

The author evaluates street vendors restructuring policy with three types of evaluation.

Pre-program evaluation (Evaluation is conducted before the program is implemented)

"Pre-program evaluation" is made before program is implemented. This is aimed (1) to measure the demand and potential of development in the target or goal area, and (2) to test the program hypothesis or to determine the success possibility for the program or project plans nayatullah [14].

Before the restructuring policy for street vendors in Surakarta City, there are many street vendors. The presence of these street vendors is not in appropriate place because they remain in public area. Some problems occur such as congestion and the distraction of city scenery. Street vendors in Surakarta City indeed have great potential to increase local genuine income. If street vendors are positioned at strategic site without disturbing traffic and city scenery, their trading activity will run smoothly and the welfare is obtained. The successful trading by street vendors cannot be separated from the policy of the government of Surakarta City to support the trading activity of street vendors by giving them some supporting facilities.

On-going evaluation (Evaluation is conducted during the implementation of program) "On-going evaluation" is defined by World Bank as "an analysis, which is oriented toward action, effect and consequence of project compared to what is anticipated in the implementation" Inayatullah [15] defines this as following:

"On-going or concurrent evaluation is conducted during the implementation of program. It is analyzing the relationship between output and effect or the possibilities of consequence 
After the street vendors restructuring policy is implemented, the problems that are successfully dealt with are congestion and the distracted city scenery. The implementation of street vendors restructuring policy has achieved the goal. The government is satisfied because the orderliness Surakarta City is gained better. Street vendors are also happy because they are given free supporting facilities to make trade without losing the customers.

World Bank describes the functions of ongoing evaluation as following:

(1)To give solution to the problem occurred during the implementation of program.

(2)To ensure whether the program target is receiving benefit from the program.

(3)To help program management to adapt with "any changes (goal and condition)" and also with the change of goal-related policy, the institutional restructuring, and the change of sources which influencing the implementation of project.

Ex-post evaluation (Evaluation is conducted after the program is accomplished)

United Nations define ex-post evaluation as a process "conducted after the implementation of program to examine the effect and consequence of the program" and it is also aimed to obtain information about:

The effectiveness of the program in achieving the determined goals.

Its contribution to the targets of planning and development at sector or national levels.

The long term consequence of the result of project.

The implementation of policy has lasted for a while and Surakarta Mayor is replaced. The author then evaluates street vendors restructuring policy in Surakarta City, especially for street vendors at Notoharjo Market and Manahan Stadium. The impact of the relocation of street vendors to Notoharjo Market is causing complains from several street vendors. The policy is not run well because many street vendors are complaining of lacking of buyers. It differs from what happens in early year when street vendors are not complaining because the business is run well. Some street vendors complain about the less optimum usage of facilities previously provided by the government of Surakarta City. The successor of the government of Surakarta City is considered not attentive to the aspiration/grievance of community because the immediate solution is not urgently searched.

\section{CONCLUSION AND RECOMMENDATION Conclusion}

This study can be concluded that (1) The relocation of street vendors in Surakarta City is orderly and smooth without violence which may impact badly on physic and material because the government of Surakarta City, especially Surakarta Mayor, uses persuasive approach, (2) Notoharjo Market is a relocation place for street vendors at Banjarsari Monument Park. In the beginning, Notoharjo Market is crowded with buyers but current days, street vendors who occupy Notoharjo Market complain about lack of buyers. The lack of buyers at Notoharjo Market is because the facilities previously provided by the government of Surakarta City are not well maintained. Notoharjo Market is rather remote from the center of Surakarta City, or about $8 \mathrm{~km}$ from the center of Surakarta City. Publication has been conducted by the government to the people of Surakarta City through pamphlet, direction sign, local newspaper and local television. Public transport route is added to pass by Notoharjo Market in order to carry the shopper to the market. (3) There are $15 \%$ street vendors or 96 street vendors at Notoharjo Market who complain about lack of buyers due to the less optimum usage of facilities provided previously by the government of Surakarta City, (4) Street vendors at Manahan Stadium, after given shelter by the government of Surakarta City, become orderly and the selling around Manahan Stadium is good so far.

\section{Recommendation}

After evaluate the policy of the restructuring street vendors, so the current government of Surakarta City must learn the policy from the previous government of Surakarta City by listening all complains of street vendors for the smoothness and orderliness of trading activity of street vendors. Not only listening, but the government of Surakarta City also gives appropriate and best solution to street vendors such that street vendors feel comfort in selling and their income is better than before. If the income of street vendors at Notoharjo Market is increasing, they may not return to the old location, Banjarsari Monument Park, because the park is public area and the beauty and 
orderliness of Surakarta City must be maintained.

\section{ACKNOWLEDGMENT}

Thanks to my loving parents, Drs. Hendri Sutikno and Ivone Savitri Frahlevi,S.Pd, also my beloved husband M.Nasirul Buldan whose always support me everytime.

\section{REFERENCES}

[1]. Manning dan Effendi. (1990) Struktur Pekerjaan Sektor Informal, dan Kemiskinan di Kota, Sebuah Studi Kasus di Diraprajan. Yogyakarta, Pusat Kajian Kependudukan.

[2]. Sasono, A. (1982) Laporan Diskusi Sektor Informal. Jakarta , Lembaga Studi Pembangunan Departement Perdagangan dan Koperasi

[3]. Dye, Thomas R. 2005. Understanding Public Policy. 11th Edition. Pearson Prentice Hall. New Jersey.

[4]. Islamy, M. Irfan. 2007. Prinsip-Prinsip Perumusan Kebijaksanaan Negara. Cetakan Ke-14. Bumi Aksara. Jakarta.

[5]. Jones, C.O. (1996) Pengantar Kebijakan Publik (Public Policy). Jakarta, Raja Grafindo Perkasa.

[6]. Miles and Hubberman (1994)
[7]. Alisjahbana, DR. Ir. MA. (2006) Marginalisasi Sektor Informal Perkotaan. Surabaya, ITS Press.

[8]. Soenarko, S.D. (2002) Public Policy: Pengertian Pokok Untuk Memahami dan Menganalisis Kebijakan Pemerintah. Surabaya, Airlangga University Press.

[9]. Berman, P. (1980) "Thinking about Programmed and Adaptive Implementation: Matching Strategies to Situation", in Why Policies Succed or Fail. Edited by Ingram and Mann, 1980. London, Sage Publication.

[10]. Jones C.O. Loc.cit

[11]. Patton, C.V. and D.S. Sawicki. (1991) Basic Methods of Policy Analysis and Planning. New Jersey, Prentice-Hall. Englewood Cliffs

[12]. Alisjahbana, DR. Ir. MA. Loc.cit

[13]. Sutisna, N. (2006) Enam Tolak Ukur Pembangunan Berkelanjutan. Jakarta,Urban And Regional Development Institute dan Yayasan Sugijanto Sugijoko. Jakarta

[14]. Nayatullah, Mathur. K dan. (1980). Monitoring And Evaluation of Rural Development: Some Asian Experiences. Kuala Lumpur, Malaysia: City Press Sdn. Bhd.

[15]. Nayatullah.Loc.cit 